Marinela Golemi*

\title{
Othello in the Balkans: Performing Race Rhetoric on the Albanian Stage
}

\begin{abstract}
This essay examines the racialized rhetoric in Fan Noli's 1916 Othello translation and the racialized performance techniques employed in A.J. Ricko's 1953 National Theatre of Albania production. Hoping to combat racial discrimination in Albania, Noli's translation of Othello renders the Moor an exceptional Turk whose alienation in Venice was designed to mirror the Albanophobic experiences of Albanian immigrants. Moreover, the Albanian Othello can serve as a platform for addressing ethno-racial tensions between Albanians and Turks, northern and southern Albanians, and Albanians of color and white Albanians. Both Noli and Ricko believed there was an anti-racist power inherent within Shakespeare's play. In the end, however, the race-based rhetoric in the Albanian language, the use of blackface make-up in performance, and the logic and rhetoric of Shakespeare's play itself challenged these lofty goals for race-healing.
\end{abstract}

Keywords: Othello, Albania, race, ethnicity, rhetoric, blackface, performance.

Othello was the first play performed and translated in Albania. ${ }^{1}$ The play was initially staged in 1890 in Korça as an amateur school performance in a church hall. An Albanian translation did not exist at the time, so the performers relied on Italian translations and their own oral performance traditions. Othello officially reappeared on the Albanian stage in 1953, as a politically-motivated performance based on Bishop Fan S. Noli's 1916 translation. ${ }^{2}$ Noli translated Othello while he was living in the United States, studying at Harvard University. ${ }^{3}$ His choice was primarily “induced by his status as an 'other', an

Arizona State University.

1 Albania is thought to be the remainder of Illyria. Fan Noli's preface to Othello notes that he is translating the play for the Albanian people in their own language - "the ancient language of the Illyrians."

2 Theofan Stilian Noli is one of Albania's most revered political and literary figures.

3 The finished translation was published by Vatra, the pan-Albanian Federation of America which Noli and Faik Konica co-founded. The translation's success inspired Noli to also translate Hamlet, Macbeth, and Julius Caesar in 1926. 
'alien' in culture, origin, complexion, like other emigrants" from Europe (Kadija 37). During his stay in Boston, Noli was inspired to translate Othello after observing the struggles of the African American community. He found the realities of immigration, alienation, and racism reflected not only in Shakespeare's play, but also in the connection between black Americans and Albanian immigrants. As a result, Othello was translated and performed with the political agenda "to attack 'racial' discrimination" (Kadija 37) in Albania. Noli's translation emphasizes that Othello is a type of "exceptional Turk," whose status in Venice was intended to be relatable to the Albanophobic experiences of Albanian immigrants in Europe.

The sentiments and prejudices Albanians shared against Turks, following centuries of Ottoman colonization, seemed to Noli to resonate in Shakespeare's Othello. ${ }^{4}$ Although he did not address this directly in his introduction to Othello, Noli's translation seems to link Othello's struggles with the experiences of marginalized Albanians of color (Afro-Albanians, Romani, Egyptians, and northern Albanians). In Albanian theater, Othello's racial overtones are performed as being ethnically, geographically, and religiously based. Therefore, the Albanianized Othello simultaneously exhibits the identity of a Turkish other, a black foreigner, and a Muslim man.

Despite the fact that A.J. Ricko's 1953 text-based production belongs to the communist era in Albania's history, Noli's translation is still reproduced faithfully today, thereby carrying old business in with the new. Noli's original translation and Ricko's 1953 production of Othello continue to inform Albania's engagement with race in modern entertainment outlets, including the problematic employment of blackface. To date, critics have neglected to comment on the racial politics of Shakespearean translations and performances in Albania, but there is a rich and complicated history that deserves to be unearthed and analyzed. This essay will trace the history of race in Albania, Noli's employment of race-based Albanian rhetoric in his translation, and Ricko's use of blackface in his wildly popular 1953 production. While both Noli and Ricko believed that Shakespeare's Othello was the right vehicle both to explore and heal Albania's racial tensions, I argue that some of the challenges faced by Noli and Ricko actually stem from the race-based logic of Shakespeare's Othello. This argument, I hope, will help demonstrate the need for an expansion of the critical engagement with Albanian translations and performances of Shakespeare.

${ }^{4}$ After centuries of Ottoman control, Albania's nationalist movement emerged, and it further fueled their ethnic pride. Albania futilely battled against their massive forces, and as a result, many had to flee to surrounding countries while approximately two thirds of the population had to convert to Islam. 


\section{Race in Albania}

Race takes on a specific meaning in Albania. As one of the oldest ethnic groups of southern Europe, race for Albanians is a delicate subject matter that is intimately woven with ethnicity. Consequently, one cannot review racial discrimination in Albania without recognizing that race and ethnicity are conflated concepts, although they are not necessarily interchangeable. The various definitions of the Albanian term rracë/rraca (race) include "origin, descent, blood, nation, phenotype, colour, body build and shape, geography, and kin" (Ohueri 39). However, ethnicity is determined by many of the same internal and external categorizations, thereby creating a gray area that has immobilized the discursive progress of race studies in Albania. Because "boundaries between race and nation are slippery" (Lemon 60), certain ethnicities are racialized phenotypically. This means that the idea of ethnic pride or ethnic nationalism could conceivably be a racialized epistemology. Due to their war-bound history, Albanians embrace their ethnicity with a sense of national pride which has inadvertently led to a rise of ethno-racial division within and without the country's borders.

The ideological value that Europeans have placed on colorblindness has rendered race invisible in Albania. Race is not given the necessary political and cultural gravitas it warrants, and racism is often not regarded as a real issue. During her field work in Tirana, anthropologist Chelsi West Ohueri recounts testimonials from Albanian natives who reveal their naive attitudes about racism in their country. ${ }^{5}$ Beyond direct denials of racism or reiterations of the claim that "there is racism everywhere" (qtd. in Ohueri 19), Albanians offered justifications for the lack of racial diversity by explaining that their xenophobia is a result of their isolation (Ohueri 6). As one of the "last European socialist countries to break with communism" (Waal 5), Albania's self-imposed isolation, following centuries of colonial rule from the Ottoman Empire, has divided Albania from the rest of the world for at least fifty years, geographically, culturally, and politically. ${ }^{6}$

In her research on race in Albania, Ohueri also records responses from residents who view themselves as victims of racism from the English, Italians, Germans, and especially, the Greeks. Despite Albania being a predominantly white country, many Albanians have experienced racism in their own migratory

5 I follow Gilroy's definition of naivety which suggests that "any aspiration to live outside of racialized bonds, codes and structures is naïve, misplaced, foolish, or devious" (xvi).

6 Robert Austin explains that under communist rule, Albanians were forbidden to watch foreign television and there was an absence of foreign literature (174). Even at the collapse of communism "Albania had adopted a form of self-reliance" which made them "the most isolated people in the world" (Austin 175). 
relations with Greece, thus placing their whiteness in question. For this reason, Albanians claim that race is understood primarily through ethnic differences rather than skin color. But to complicate matters, an interlocutor categorizes Albanians as "the $\mathrm{n}^{* * * * *} \mathrm{~s}$ of Europe" $(84) .{ }^{7}$ Misguided as it may be, this respondent's analogy between the racial discrimination perpetuated against blacks in the US and the discrimination faced by Albanians in Europe is symptomatic of a lack of a coherent Albanian discourse for racism and the unequal distribution of power, rights, and goods based on constructions of race.

Moreover, many Americans and Europeans retain an outdated and stereotypical image of Albanians as violent and blood-thirsty from $19^{\text {th }}$ and $20^{\text {th }}$ century travel writing. Albania has been noted as the "ideal Balkan type -violent, independent, and at times untrustworthy," for it "both touched Lord Byron's creative fantasies and haunts Robert Kaplan's recent travels" (Blumi 528). In letters he wrote to his mother, Lord Byron famously romanticized his time in Albania by describing "Albanians in their white, gold and crimson dresses (the most magnificent in the world)" (Bhattacharji 40). In 1813, he even commissioned a self-portrait in rich Albanian garbs. Byron's exoticization of Albania as a strange and savage land was repeated by the British travel writer Edith Durham, who expressed a sympathetic attitude toward these "unfortunate and childlike nations," while she romanticized their "ancient customs of archaic Balkan violence" (Schwandner 122). Likewise, the German writer, Karl May projected an image of Albanians as the world's real "noble savages"- not only courageous and brave, but also "corrupt, violent, dirty, [and] poor" (Schwandner 121). This stereotypical image of the Balkans, Maria Todorova avers, was set and consistently reproduced during World War I (184). ${ }^{8}$ In its wake, the imagery and rhetoric of the noble but backwards Balkan personality has been perpetuated for decades in the media around the world. Albanians have internalized these ethnic stereotypes as is evidenced by their recorded responses to racism.

Albania's ethno-racial politics are transcribed spatially and are fostered through imaginary racial-spatial boundaries. Primarily, there is a racial division between northern and southern Albania, or as an Albanian interviewee suggests, "the real racism comes from political parties [...] they perpetuate racial divisions between city and mountain folk" (Ohueri 97). The glorified violent practices of the Kanun ${ }^{9}$ are assigned to the northern Albanians from the mountains, who are

${ }^{7}$ Alaina Lemon describes the slipperiness between race and nation through the Romani people whose blackness became a signifier of being a "true Gypsy" (60). Lemon interviews a Romani man who complains: "we are negry; we are treated like second class here, like your blacks in America" (60).

${ }^{8}$ This image is reflective of "Balkanization," a negative connotation that means to break up a geographic area into small and often hostile units (Todorova 33). In other words, Albania is repeatedly viewed as a place of destitution, turmoil, and political chaos.

${ }^{9}$ The Kanun is a set of customary Albanian laws, much like a strict conduct book. 
derogatively called "malok," meaning highlander (Schwandner 119), because they border with surrounding Balkan nations. ${ }^{10}$ While northern Albanians are not people of color, they do face racial exclusion if one acknowledges that racism is a system built on sustaining inequalities of power. Race, Ayanna Thompson argues, does not have a stable of fixed meaning, and it can be "signified by something that is unseen, hidden, and/or invisible" (Performing Race 19). Some Albanians insist that racial divisions are not determined by blackness or whiteness, but rather by geography and ethnicity.

However, the urban/rural divide fails to account for phenotype-based racial discrimination which directly affects those classified as dorë e zezë (black) from the dorë e bardhë (white). ${ }^{11}$ Blackness and whiteness in Albania are characteristics for differentiating white Albanians from black Romani and Egyptians. Gypsiness is discussed in ethnic rather than racial terms (Mudure 277), despite the fact that some of these "Gypsy" communities identify as Albanians. Roma and Gypsy-Travelers "play the part of 'the Stranger', the internal outsider" (Mudure 149). Although Alma Hoti insists that it is difficult to measure racial discrimination because race is a changing concept (72), the marginalization of Roma people in Europe is widely documented in data that shows the violence perpetrated against these groups, as well as the income disparities - due to lack of labor integration and shelter - that are allowed to flourish. In Albania specifically, the Committee on the Elimination of Racial Discrimination reported that "Roma and Egyptians were among the poorest, most marginalized and socially excluded groups." ${ }^{12}$ Racial discrimination of Gypsy or Tsigani people follows a long history of targeted abuse as indicated by the history of medieval Gypsy slavery in Europe (Heng 440). Romani history, Geraldine Heng states, proves that race is not a modern concept at all, but one that can be traced in medieval Europe (Heng 449). The influence of western European culture becomes visible when unpacking the racial conflicts between Gypsies and Albanians.

\section{Race Rhetoric in Translation}

Shakespeare is a global phenomenon valorized for his cultural fluidity, but if that fluidity is oblivious to the inherently racialized ideologies of Shakespearean plays, then cultures risk reproducing imperialist credos through their faithful

\footnotetext{
${ }^{10}$ The divide between north and south Albania is also distinguished by language and dialects.

${ }^{11}$ Dorë e zezë literally translates as "black hand," referring to the blackness of Roma and Egyptians in contrast to the whiteness of dorë e bardhë (white hand) Albanians.

12 Hoti reveals that "Egyptian and Rom communities are recognized as linguistic minorities, not as national minorities" (70) in Albania.
} 
translations. Fan Noli's attempt to bring Shakespeare to Albania as a means of bringing Albania to the world serves as a prime example of this colonial cycle. Noli considered Shakespeare the "greatest dramatist in the world after Christ" (Noli 5), and he wished to grant his people access to great literature, so he "Albanianized" Othello. ${ }^{13}$

Shakespeare entered Albania at a time of war. In her reception study of Shakespeare in Albania, Enkelena Qafleshi explains that Shakespeare flourished in Albania because Noli's commentary framed his work as being in concert with the historical moment of the country (44). Albanians "were fighting for freedom, independence, integrity of the country, dissemination of Albanian language, [and] preservation of Albanian culture," and Shakespeare grew popular amongst them because his works were used as propaganda to address such concerns (Qafleshi 45). As a liberal politician, Noli had his own political agenda for translating Shakespeare's tragedies. ${ }^{14}$ Noli favored Shakespearean tragedies for their relatability to the stories of his war-torn country, but he deliberately translated Othello first because he imagined the play would relate and reflect the racialized experiences of Albanian immigrants.

Yet, Othello is a race play and its racialized language and themes easily transfer in translations. For this reason, the play forbids audiences from forgetting Othello's blackness by invoking imagery of "an old black ram" topping a "white ewe!" (1:1:97-88), or by describing Othello as "a Barbary horse" (1:1:110), and by repeatedly referring to him as black and/or Moor rather than Othello. ${ }^{15}$ Such racialized rhetoric is reflected in the Albanian translations, despite Noli's reassurance that "Othello had a black face, but was great, kindhearted and beautiful in spirit and in heart" (Noli 7). Noli admires Othello for being a self-made warrior, who is "brave, loyal, just, and naïve," and yet who must remain in Venice "a stranger and black" (Noli 6). Alfred Uçi, one of the premier Albanian Shakespeare critics influenced by Noli, refers to Othello as a "white-hearted" person whereas "Iago is white-skinned but his soul is black" (123). This is presented as a moral lesson, not a racial one. Blackness is confined to a symbolic role of $\sin$ that is manifested outwardly and assigned indiscriminately to the Moor. Although it is Iago, not Othello whom Noli labels as a "black demon" (166), the stigma of blackness is not overturned by Noli's interjection since it remains woven in language.

Othello's intrinsic racial themes are furthermore reinforced through the fundamentally racialized rhetoric of the Albanian language. For example, the

\footnotetext{
${ }^{13}$ All English translations from Albanian are mine.

${ }^{14}$ Kadija claims that "there was a political motivation behind every Shakespearean play either staged or translated" (38).

${ }^{15}$ References to Othello are to the Arden Shakespeare, edited by E.A.J. Honigmann, with a new introduction by Ayanna Thompson (2016).
} 
line "The Moor is of a free and open nature" (1:3:398) becomes "The Moor is by nature white-hearted" (Noli 44). The kindness and naivety of Othello's nature in Albanian is understood through racial descriptors of whiteness. The slipperiness of the term Moor is equally difficult in its Albanian translation. Arap (moor) in Albanian is used as a "chromodermal signifier" (Smith 35) to derogatorily refer to Turks, Africans, and Gypsies - basically anyone who is non-white. There is of course the unmistakable proximity between Arap and Arab which invites the common, but misguided, conflation of Arab and Muslim. For instance, when Noli describes Othello as the black Arap (7), he is simultaneously emphasizing his blackness while also assimilating an ethnic and a religious identity into one. Thus, the Albanian Othello rhetorically embodies the racialized identity of a Turkish other, a black foreigner, and a Muslim man. All these associations are burdened unto one word which is then burdened unto a body.

In Albanian culture, blackness is a sign of malady, of being accursed. For instance, when Brabantio exclaims, "With the Moor, say'st thou?-Who would be a father?" (1:1:163), Noli translates it as: "With whom, the Moor, you said? Oh, I am black!" (Noli 22). ${ }^{16}$ Brabantio's blackness here is not literal, it is symbolic. Because Brabantio considers fatherhood a burden, Noli uses the common expression "I am black" to indicate his fatherly misfortune. Similarly, Desdemona's line "It is my wretched fortune" (4:2:129) is translated as "thus has been my black fortune" (Noli 139). This also serves as a pun that ties her "black" wretched fortune to her "black" wretched husband. Desdemona becomes "rhetorically black" (Hall 22) since her social and marital value has been blackened by her proximity to the Moor. It is precisely this "insistent association of black as a negative signifier of different cultural and religious practices with physiognomy and skin color," Hall argues, that "pushes this language into the realm of racial discourse" (6). Both Brabantio and Desdemona's translated exasperations describe a racialized understanding of their misfortunes. This racial emphasis is possible because the medieval associations of blackness with sin still thrive in the Albanian language and culture.

Noli does not provide footnotes for these references to race, ethnicity, or religion, nor does he justify his explicitly racializing translation choices. For example, the rhetoric in Desdemona's "Willow" song is racialized by blackening the willow. Noli translates the line "Sing all a green willow (4:3:40) as "Weep, willow, o black willow" (146). These lyrics rely on the same cultural signification of blackness as ill-fated to indicate Desdemona's misery as the one's cited above. Thus, the willow is transformed into a symbol of racialized grief. While a "green willow" symbolizes the natural green color of a tree as well as jealousy "the green-eyed monster" (3:3:168), a "black willow"

\footnotetext{
${ }^{16}$ Noli's Othello translation uses page instead of line numbers.
} 
symbolizes an unnatural grief that stems from Othello's blackness. Race is of course not limited to a binary of black and white, but in this Albanian context Othello's otherness is nonetheless colored by the country's race politics.

\section{Race Rhetoric in Performance}

In 1953, Noli's translation of Othello reached the Albanian stage under the direction of A. J. Ricko. It was "staged 40 times for a number of 23,747 spectators until 1964" at the National Albanian Theater (Qafleshi 110). ${ }^{17}$ It was incredibly popular and helped to establish the centrality of the theatre in the Stalinist-leaning Albanian government. While the production was poorly documented, Q.M.K.SH has released an image from the production featuring the actor Loro Kovaçi who appears to be performing as Othello in blackface makeup. ${ }^{18}$ In this Albanian performance of Othello, "race is colored," to borrow a phrase from Thompson (Performing Race 51), and in doing so, the performance represents blackness as performative. Because "the trope of blackness is applied to groups that need to be marked as other" (Hall 7), Othello's cosmetic blackness corporeally signifies physical, geographical, and religious difference. "The black African on the stage," Smith claims, "is visibly fixed in an intractable series of 'devil' stereotypes that require no further knowledge beyond the skin" (35). Ricko's 1953 production of Othello attempted to address race in Albania, but it did so by using the wrong tools. Rather than promoting racial unity, the use of racial prosthetics in his Albanian performance failed to distort the racial politics of Othello because blackface practices sustain stereotypes about the performativity of blackness. Thus, Othello's racial difference was highlighted, not erased.

Othello, Kadija notes, "was the first Shakespearean play to be staged and performed by the Albanian National Theatre" to combat racial discrimination by emphasizing "the theme of the 'other', alienation, loneliness, the life of a soldier, the discrimination of a coloured man"-all of which would

${ }^{17}$ The text was later transformed by directors L. R Kiçko, B. Levonja, and A. Pano whose "scissor approach" omitted several characters and cut off the second scene of act two (Qafleshi 51).

18 Qendra Mbarëkombëtare e Koleksionistëve Shqiptarë (International Center of Albanian Collectors): https://www.qmksh.al/21-mars-1953-premiere-e-otellos-neteatrin-popullor/. The collection includes a black and white image and one in color. It is unclear whether they are from the same production. The use of blackface is especially apparent in the color image. More photographic documentation of the blackface performance can be found on the National Theater's social media account. 
hold special resonance for Albanian audiences (37). ${ }^{19}$ Regardless of the play's negative images of Turks, Othello's perceived foreignness in Venice and Cyprus was relatable to many Albanians who faced similar discrimination when migrating from the Balkans. Respectively, the northern Albanians, Romani, and Egyptians expressed their felt exclusion from Albania's mainstream sociopolitical culture just like Othello.

In Ricko's production, Othello is treated as the exceptional Turk, "a central black figure who appears to supersede the prevailing black stereotype" (qtd. in Smith 35), in order to show Albanians that regardless of his hue, the character is essentially Albanian and white. This notion is complicated given that in performance "Othello was a white man" (Callaghan 76). Any anxieties the audience might have had about the "black Turk" could be nullified simply by the removal of the black makeup. For this reason, Ian Smith argues that "the prosthetic black body" on stage only validates the "native whiteness" underneath (36). Relying on Othello's static whiteness beneath the surface as a means of promoting racial unity between Albanians of color and white Albanians is a colorblind approach that enforces whiteness as the norm. Thus, the privileged union of a predominantly white audience enables the production of the "white/right gaze" (Thompson, Performing Race 20) under which racialized bodies become constructed spectacles on the stage.

While the racialized rhetoric encoded in Noli's translation alludes primarily to racial attitudes against Turks, Ricko's 1953 Othello production also relied on the ethno-racial conflicts between Gypsy communities and Albanians. This relation is not strenuous given that the discrimination against Gypsies is in part due to their association with Turks. Moreover, the racial themes in Othello allow for the reflection of the ethno-racial tensions between white Albanians and Afro-Albanians, ${ }^{20}$ a term I borrow from Mustafa Canka to refer to African Albanians of color, who are also affected by the racial representation of Othello in theater.

${ }^{19}$ Othello's jealous nature also contributed to play's popularity among stereotypically jealous Albanian men. Albanian culture is heteronormative and still upholds patriarchal values; thereby, cuckoldry and betrayal are relatable causes for masculine anxiety. As Kadija asserts, "the betrayal of fathers holds particular weight in patriarchal Albanian families" since they maintain a strong patriarchal system (38). Desdemona's betrayal of her father would have struck a chord for Albanian fathers.

${ }^{20}$ Canka discloses that during the Mediterranean wars of the $19^{\text {th }}$ century, many countries resorted to slavery to fill their fleets. Ulcincj, Montenegro, now located above Albania, kept slaves as prisoners for labor or for ransom. The "Afro-Albanian" slaves became free working citizens as they integrated into their communities (Canka). 
Despite Ricko's production with an exceptional Othello who is black yet "white-hearted in nature" (Noli 44), there is no way to control or predict an audience's reaction to his racialized body because "power resides almost entirely with the [white Albanian] spectator" (Callaghan 77). To that end, the use of racial prosthetics is not in concert with a colorblind ideology; rather, their use exposes the lack of racial diversity among the cast and the audience. Unfortunately, this contributes to the continuous use of outmoded blackface practices in Albanian theater and television. ${ }^{21}$ Noli and Ricko have left their blackface mark on Albanian performance history.

\section{Conclusion}

In adopting western literature, specifically Shakespeare's canon, countries of non-European status like Albania, risk the appropriation of the racial ontologies that are engulfed within that imperial culture. Racism cannot be easily erased from western history because it "is built into Britishness, and Britishness is built on racism" (qtd. in Bancroft 39). Once that western ideology of racial difference has infiltrated the non-European or Balkan nations, then "Western European nations use evidence of racism in Central and Eastern Europe to 'orientalize' racism" (Bancroft 3). Racialized borders, Agnes Czajka notes, also separate Western from Eastern Europe by linking slavery with East Europeans (Slavs) (210). Thus, the West others racism and takes on a centralized identity of racelessness "by which racial thinking and its effects are made invisible" as if race exists anywhere but Europe (El-Tayeb xvii). Nonetheless, Albanians have aspired to the status of "European" and for inclusion in the European Union because of the enduring myth of the West. The West, Fatos Lubonja explains, was idealized in communist Albania, first as the "Promised Land," a utopia of sorts, and second, as the "Saviour," a singular source of benevolence and justice (131). This myth has been diluted but not destroyed. Consequently, Albanians' attitude toward racelessness seems derivative of the ideological value Europeans place on colorblindness - unable "to pinpoint a stable signification for race," Albanians "replicate the anxieties [their] society has about defining race" through colorblind practices (Thompson, Colorblind Shakespeare 8). Europe's colorblind approach to race oppresses legitimate racialized discourses and therefore stunts potential resolutions. Goldberg astutely comments: "Nonracialism squeez[es] out any possibility of anti-racism" (349). Albania's ethno-racial politics are situated within a larger European notion of racelessness that

${ }^{21}$ Ohueri points to an example in the television comedy show Portokali, wherein a white Albanian actor impersonates an African football player using blackface and accented speech (5). 
rationalizes racist practices like blackface, and Shakespeare can be found at center of it all. ${ }^{22}$

When it comes to theatrical spectacles, Dympna Callaghan distinguishes between two modes of racial representation: exhibition which is the "display of black people," and mimesis which refers to "the simulation of negritude" (77). In the Albanian production of Othello, the racial prosthetics functioned as an exhibition of a Turkish identity that was nonetheless mimetic because it reproduced blackness as performative. Even by portraying Iago as internally black, Noli's translation and Ricko's production comply with and reinforce stereotypes of blackness. Although Noli's sympathy for Othello intended to elicit a similar affinity from the audience as a means of mending a bridge between white and non-white Albanians, that sympathy did not translate onto the stage. Despite the spectacle of "the amiable Othello" (qtd. in Othello 56), Ricko's blackface production rendered him a spectacle. Noli's political agenda to combat racial discrimination through the theater was distorted by Ricko's decision to employ blackface. Moreover, the choice to use a race play that disparages people of color to combat racial discrimination and promote racial unity seems contradictory at best. Othello's inherent toxicity is particularly traceable and unavoidable in a homogeneous nation like Albania. ${ }^{23}$

The existence of negative significations of blackness in Albanian language further complicates a blackened-up performance. It is uncertain whether Albanian performers are aware of the history of blackface in medieval and early modern Europe. But blackface performances of Othello do not and cannot so easily subvert the medieval correlation of black and evil like Noli intended. As Paul Gilroy's states, "Any fool knows that real, grown-up governments cannot legislate the emotions of their populations" (xvi). A more desirable outcome is to invite a discourse that deliberates on the significance of race in performance for both actors and audiences rather than hoping to train audiences to not see race (Thompson, Colorblind Shakespeare 12). Reception theory can further demonstrate this point. For instance, Anat Gesser Edelburg evaluated "the effects of political performances on the opinions of their audiences" with a race-based questionnaire that they answered prior and after the show (Sauter 255). Willmar Sauter performs the same experiment as a means of testing the anti-Semitic effects of The Merchant of Venice on audiences. The results revealed that the play did in fact enhance and confirm stereotypes about Jews (257). I imagine that an extension of this essay would benefit from

${ }^{22}$ Ayanna Thompson proposes that the name Shakespeare employs many "meanings, references, and ambiguities" and it is important to "capitalize on these multiplicities" (4). My use of the name Shakespeare in this essay references this multiplicity.

${ }^{23}$ While I don't believe it is yet possible to do Othello "right" in Albania, its complexities create a necessary space for a discourse on race. 
a similar form of reception research that investigates the reception of Othello in Albania. Beyond Othello, I propose instead that a bilingual and intracultural production of Romeo and Juliet performed by northern and southern Albanians, or white and Roma Albanians would render the stage a neutral space for reconciliation, and therefore combat racism by Albaniazing Shakespeare in a way that Othello cannot. ${ }^{24}$

Ricko's 1953 production was vastly successful, and the actors were highly praised for their performances. However, based on the lingering stereotypes about Turks and the existing racial division between Albanians of color and white Albanians, it is evident that Othello did not achieve its initial purpose on the Albanian stage. The print translations accompanied by Noli's introduction were also unsuccessful since they emphasized racial differences rhetorically, despite Noli's insistence of Othello's exceptional blackness. Ultimately, the translation failed to carry this message since Noli's commentary which glorified Othello was erased from the later 1977 reprints (Belluscio \& Koleci 237). The only form of control the translator maintained over his readers was to pave how Albanians got to know Shakespeare, but even that can change.

\section{WORKS CITED}

Austin, Robert. "Less is More: Towards a Sustainable and Reliable Media in Albania." Ed. Marta Dyczok et al. Media, Democracy and Freedom: The Post-Communist Experience. Switzerland: Peter Lang, 2009.

Bancroft, Angus. Roma and Gypsy-Travellers in Europe: Modernity, Race, Space, and Exclusion. Burlington: Ashgate, 2005.

Barthelemy, Anthony Gerard. Black Face, Maligned Race: The Representation of Blacks in English Drama from Shakespeare to Southern. London: Louisiana State University Press, 1987.

Belluscio, Gjovani and Flora Koleci."Veçori gramatikore dhe strategji origjinale në përkthimin e "Othellos" së Fan Nolit nga anglishtja." Fan S. Noli me 130 vjetorin e lindjes 1882-2012: Konferenca Shkencore Ndërkombëtare. Korçë: Fakulteti i Edukimit dhe Filologjisë, 2012. 232-244.

Bhattacharji, Shobhana. "I Like the Albanians Much': Byron and Three TwentiethCentury British Travellers to Albania." The Byron Journal 38, no. 1, (2010): $39-48$.

Blumi, Isa. "The Commodification of Otherness and the Ethnic Unit in the Balkans: How to Think about Albanians." East European Politics and Societies 12, no. 3 (1998): 527-569.

\footnotetext{
${ }^{24}$ Miki Manojlović's 2015 bilingual and intracultural production of Romeo and Juliet successfully confronted the ethnic conflict between Kosovo and Serbia as Kosovan Montagues and Serbian Capulets performed together on an X-shaped stage, making the performance itself an act of reconciliation.
} 
Callaghan, Dympna. Shakespeare without Women: Representing Gender and Race on the Renaissance Stage. London: Routledge, 2000.

Canka, Mustafa. "Only Memories and Emptiness Remain: The History of Ulcinj's AfroAlbanian Community in Montenegro." LeftEast, 2013. https://www.criticatac. ro/lefteast/only-memories-and-emptiness-remain-the-history-of-ulcinjs-afroalbanian-community-in-montenegro/

"Committee on the Elimination of Racial Discrimination Considers the Report of Albania." OHCHR, Geneva, 2018. https://www.ohchr.org/EN/NewsEvents/ Pages/DisplayNews.aspx?NewsID=23976\&LangID=E

Czajka, Agnes and Jennifer Suchland. "Mapping the Margins of Europe: Race, Migration, and Belonging." PhiloSOPHIA 7, no. 2 (2017): 205-214.

De Waal, Clarissa. Albania Today: A Portrait of Post-Communist Turbulence. London: I. B. Tauris, 2005.

El-Tayeb, Fatima. European Others: Queering Ethnicity in Postnational Europe. Minneapolis: University of Minnesota Press, 2011.

Goldberg David. "Racial Europeanization." Ethnic and Racial Studies 29, no. 2 (2006): 331-364.

Hall, Kim F. Things of Darkness: Economies of Race and Gender in Early Modern England. Ithaca: Cornell University Press, 1995.

Heng, Geraldine. The Invention of Race in the European Middle Ages. New York: Cambridge University Press, 2019.

Hoti, Alma. "Racial Discirmination in Albania and The Role of the Commissioner of Protection Against Discrimination (CPD) Analysis of Cases of Racial Discrimination Time Period 2010-2014." Global Journal of Politics and Law Research 3, no.6 (2015): 67-95.

Kadija, Refik. "William Shakespeare in Albania." Linguistic and Communicative Performance 2, no.1 (2009): 36-43.

Lemon, Alaina. "Without a 'Concept'? Race as Discursive Practice." Slavic Review 61, no. 1 (2002): 54-61.

Lubonja, Fatos. "Albania After Isolation: The Transformation of Public Perceptions of the West." Ed. Andrew Hammond. The Balkans and the West: Constructing the European Other, 1945-2003. England: Routledge, 2004.

Mudure, Mihaela. "Blackening Gypsy Slavery: The Romanian Case." Ed. RaphaelHernandez. Blackening Europe: The African American Presence. New York: Routledge, 2004.

Noli, Fan Stylian. Trans. Tragjedia e Othello's Arapit Te Venetikut (1604). Boston: VATRA, 1916.

Ohueri, Chelsea W. "Mapping Race and Belonging in the Margins of Europe: Albanian, Romani, and Egyptian Sentiments.” Diss. University of Texas at Austin, 2016.

Qafleshi, Enkelena Shockett. "How Shakespeare Was Received in the Albanian Literture and Culture - a General History." Linguistic and Literary Broad Research and Innovation 3, no. 1 \& 2 (2014): 42-56.

Qafleshi, Enkelena. Rikthim Tek Shekspiri: Studim Monografik. Tirana: Geeer, 2008. Sauter, Willmar. "Thirty Years of Reception Studies: Empirical, Methodological and Theoretical Advances." About Performance 10, no. 1 (2010): 241-263. 
Schwandner-Sievers, Stephanie. "Albanians, Albanianism and the Strategic Subversion of Stereotypes." Ed. Andrew Hammond. The Balkans and the West: Constructing the European Other, 1945-2003. England: Routledge, 2004.

Shakespeare, William. Othello. The Arden Shakespeare. Third Series. Rpt. Ed. E.A.J. Honigmann. New York: Bloomsbury, 2016.

Smith, Ian. "White Skin, Black Masks: Racial Cross-Dressing on the Early Modern Stage." Renaissance Drama 32 no.1 (2003): 33-67.

Thompson, Ayanna. Colorblind Shakespeare: New Perspectives on Race and Performance. New York: Routledge, 2006.

Thompson, Ayanna. Performing Race and Torture on the Early Modern Stage. New York: Routledge, 2008.

Todorova, Mariia Nikolaeva. Imagining the Balkans. Oxford: Oxford University Press, 1997. 